\title{
Can ameloblastomas arise from odontogenic keratocysts?
}

\author{
- Juliana Rodrigues Rozatto Unit of Oral and Maxillofacial Surgery, Santa Casa de São Paulo School of Medical Sciences, \\ São Paulo, SP, Brazil • Alan Motta do Canto Unit of Oral and Maxillofacial Surgery, Santa Casa de São Paulo School of \\ Medical Sciences, São Paulo, SP, Brazil - Paulo Henrique Braz-Silva Department of Oral Medicine, University of São Paulo, \\ School of Dentistry, São Paulo, SP, Brazil • Ronaldo Rodrigues de Freitas Unit of Oral and Maxillofacial Surgery, Santa Casa \\ de São Paulo School of Medical Sciences, São Paulo, SP, Brazil
}

ABSTRACT | Background: The ameloblastoma is a locally aggressive odontogenic tumour that has high recurrence rates. It rarely presents a histological aspect similar to the odontogenic keratocyst, because of the presence of keratinised areas. This study aimed to report a case of ameloblastoma in the mandible, diagnosed and treated incorrectly as an odontogenic keratocyst because of unusual macroscopic characteristics and rare histological aspects that impaired a correct diagnosis. Case report: A 57-year-old female patient, presenting an asymptomatic lesion at the left mandibular angle, was treated by incisional biopsy and decompression. The histological sections showed an aspect suggesting odontogenic keratocyst. At the 3-year postoperative period, the patient returned with a new lesion on the left side of the mandible and was then subjected to curettage. The histological sections showed a pattern of ameloblastoma and, because of this, the patient remained with a 6-month follow-up. At the 4-year postoperative period after the second operation, the patient returned with a new recurrence. The biopsy showed an ameloblastoma and the patient was submitted to mandibular resection and reconstruction as treatment. After the final procedure, the recovery was uneventful and the patient is now undergoing a postoperative period of four years, without recurrences. Conclusion: This case highlights the importance of carrying out a proper biopsy and an adequate examination by a specialised professional, because of the possibility of atypical lesions occurring restricted to the head and neck region.

DESCRIPTORS | Ameloblastoma; Jaw; Odontogenic Tumors.

RESUMO | Os ameloblastomas podem surgir a partir dos queratocistos odontogênicos? • Introdução: O ameloblastoma é um tumor odontogênico localmente agressivo, com altas taxas de recorrência. Raramente o ameloblastoma apresenta aspecto histológico semelhante ao queratocisto odontogênico devido à presença de áreas queratinizadas. O objetivo deste estudo é relatar um caso de ameloblastoma na mandíbula, diagnosticado e tratado incorretamente como um queratocisto odontogênico devido a características macroscópicas incomuns e aspectos histológicos raros que prejudicaram um correto diagnóstico. Relato de caso: Paciente do sexo feminino, 57 anos, apresentando lesão assintomática no ângulo mandibular esquerdo tratado inicialmente com biópsia incisional e descompressão. Os achados histológicos mostraram um aspecto sugestivo de queratocisto odontogênico. No pós operatório de 3 anos, a paciente retornou com uma nova lesão no lado esquerdo da mandíbula e foi então submetida a curetagem. Desta vez, as seções histológicas mostraram um padrão de ameloblastoma e, devido a este fato, a paciente permaneceu com um seguimento de 6 meses. No pós operatório de 4 anos da segunda operação, a paciente retornou apresentando nova recidiva. A biópsia mostrou um ameloblastoma e a mesma foi submetida a ressecção mandibular e reconstrução como tratamento. Após o procedimento final, a recuperação foi sem intercorrências e a paciente passou por um pós-operatório de quatro anos sem recidivas. Conclusão: Este caso destaca a importância de se realizar uma biópsia e um exame adequado por profissional especializado, devido à possibilidade de lesões atípicas que ocorrem restritas à região da cabeça e pescoço.

DESCRITORES | Ameloblastoma; Maxilares; Tumores Odontogênicos.

CORRESPONDING AUTHOR | - Ronaldo Rodrigues de Freitas Unit of Oral and Maxillofacial Surgery, Santa Casa de São Paulo School of Medical Sciences • R. Dr. Cesário Mota Junior, 112, Vila Buarque São Paulo, SP, Brazil • 01221-020 Email: rrdefreitas@hotmail.com

- Received Sep 05, 2015 • Accepted Oct 15, 2015

- Dol http://dx.doi.org/10.11606/issn.2357-8041.clrd.2015.125704 


\section{INTRODUCTION}

Odontogenic tumours are lesions from epithelial, ectomesenchyme, and/or mesenchyme elements, which were or are part of the tooth forming apparatus. According to the World Health Organization, these tumours are found exclusively in the maxillofacial region and can occur at any age. ${ }^{1}$

The ameloblastoma is a benign epithelial odontogenic neoplasia derived from cellular components of the enamel organ, and it is the second most common odontogenic tumour, accounting for about $1-2 \%$ of all tumors and cysts of the jaws. ${ }^{1,2}$

The clinical presentation of ameloblastomas is variable. However, it is commonly associated with asymptomatic bulges in the posterior mandible. Regarding the imaginological aspect, these neoplasms may present a uni or multilocular pattern, with well-defined margins, and they are associated with impacted teeth in most cases. ${ }^{1,3}$

Due to painless growth and prevalence in the posterior region of the mandible, the odontogenic keratocyst is considered one of the differential diagnoses of ameloblastoma. This lesion also has a slow growth; it is asymptomatic and mostly has a unilocular radiographic appearance. ${ }^{4}$

In addition to these similarities, hybrid or combined lesions of odontogenic keratocyst and ameloblastomas that impaired diagnosis have been described in the literature. Geng et al. ${ }^{4}$ reported a case of a patient who had a lesion in the maxilla with histological features similar to keratocyst and ameloblastoma. On this occasion, due to the predominance of keratinised epithelium areas, the authors classified the neoplasm as a solid keratocyst associated with ameloblastic transformations.

By these similarities between clinical, histological, and imaginological characteristics, a correct diagnosis is mandatory to carry out the appropriate treatment, bearing in mind that the behaviour of these two lesions differs in many aspects.
Therefore, it is recommended to perform a proper biopsy, collecting several samples from the lesion to help the anatomopathologic study.

This study aimed to report the case of a patient with an ameloblastoma at mandibular angle treated erroneously as an odontogenic keratocyst because of improper diagnosis and similar features.

\section{CASE REPORT}

A 57-year-old female patient was referred to the Maxillofacial Unit of the Santa Casa de São Paulo School of Medical Sciences, SP, Brazil. At the time, she had an increase of painless volume in the left mandibular angle topography with 6 months of evolution.

The skin of the region had a normal appearance, and the mucosa associated with the bulge was unchanged. Radiography showed a lesion of approximately $1.5 \mathrm{~cm}$, unilocular, radiolucent, and with well-defined margins in the left mandibular angle region (Figure 1A; 1B). At the time, the hypothesis was of a unicystic ameloblastoma, and an incisional biopsy was performed to confirm the diagnosis. During the biopsy procedure, yellowish fragments were observed, suggesting keratin, which is clinically compatible with odontogenic keratocyst. From this, a small area of the lesion was removed for histopathology and, at the same time, a decompression device was installed for the treatment.

The histological sections showed odontogenic neoplasm of cystic organisation, covered by keratinised stratified squamous epithelium. The capsule consisted of dense connective tissue that showed a diffuse mild mononuclear cell infiltration. There were no epithelial islands immersed in the conjunctiva capsule (Figure 2A; 2B).

Due to these facts, the final diagnostic of the lesion was odontogenic keratocyst, and the patient was followed clinically and radiographically to observe signs of lesion regression. The lesion responded well to the treatment and showed total 
regression in eight months. The patient was monitored every six months in a period of two years.

Curiously, in the three-year postoperative period, the patient returned complaining of jaw bulge in the operated area. New imaging tests detected a small unilocular lesion in the left ramus mandibular region (Figure3A; 3B). Considering this fact, the diagnosis of recurrence of keratocyst was suggested and the proposed treatment was curettage of the lesion complemented by peripheral ostectomy.
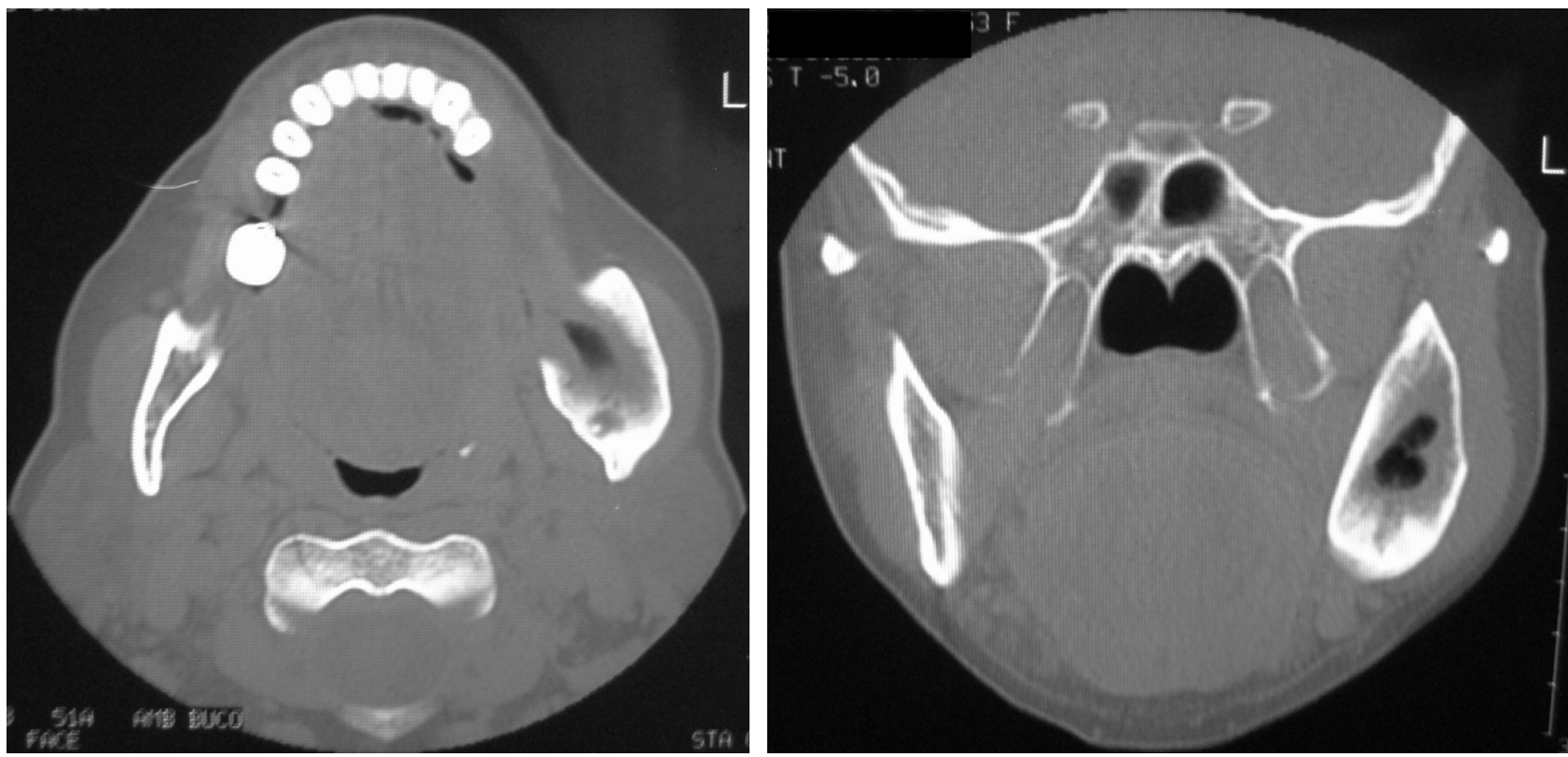

Figure 1 | A, B: Bone CT scans showing the unilocular aspect of the tumour associated with lateral bulge and the absence of cortical fenestration. Note the heterogeneous pattern of the lesion and areas with hypodense aspect.
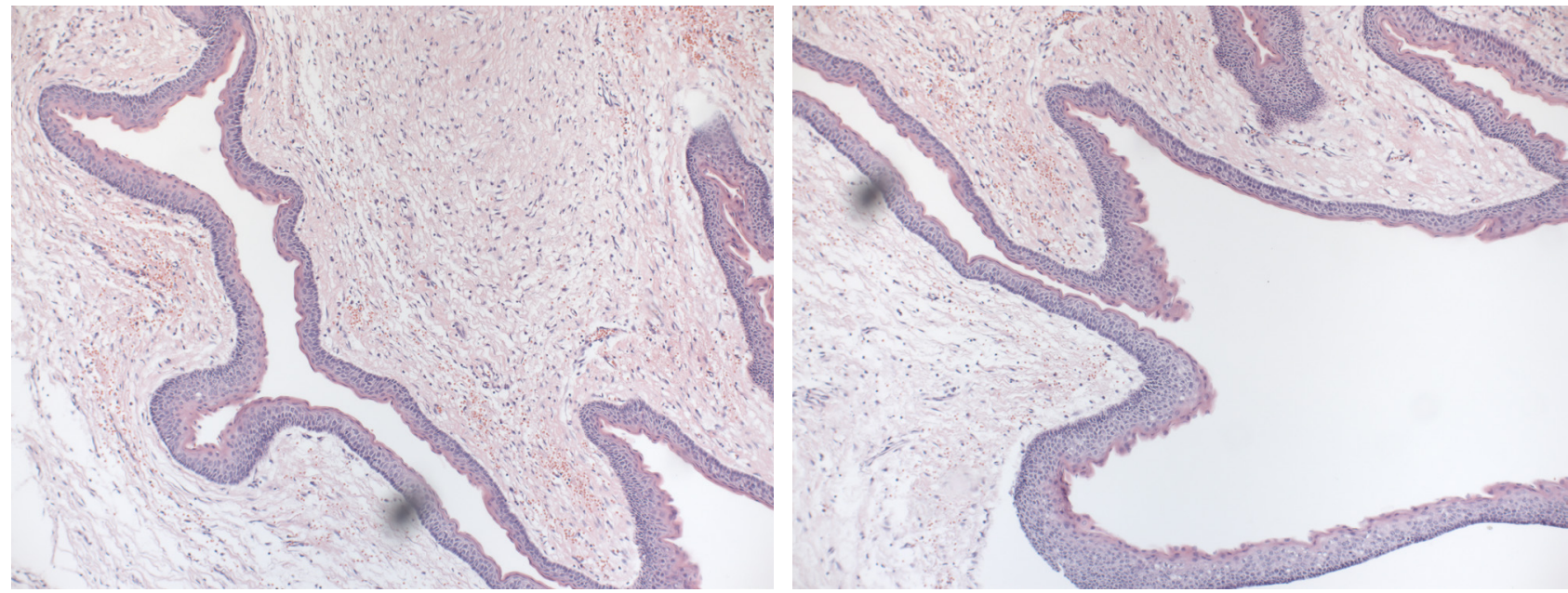

Figure 2 || A: Histological sections showing cystic arrangement, covered by keratinised stratified squamous epithelium. B: The capsule consisted of dense connective tissue that showed diffuse mild mononuclear cell infiltration. There are no epithelial islands immersed in the conjunctiva capsule. 
The curetted surgical specimen was sent back for pathological and anatomical examination, and the results were compatible with ameloblastoma. The histological sections showed large cystic spaces covered by odontogenic epithelium. The stromal lesion consisted of dense connective tissue and, immersed in it, numerous odontogenic epithelial islands were found. Peripheral epithelial cells had assumed a palisade arrangement and had reverse nuclear polarisation and hyperchromatism. They were more loosely arranged at the center, with a appearance similar to the stellate reticulum of the enamel organ (Figure 4.A; 4.B).
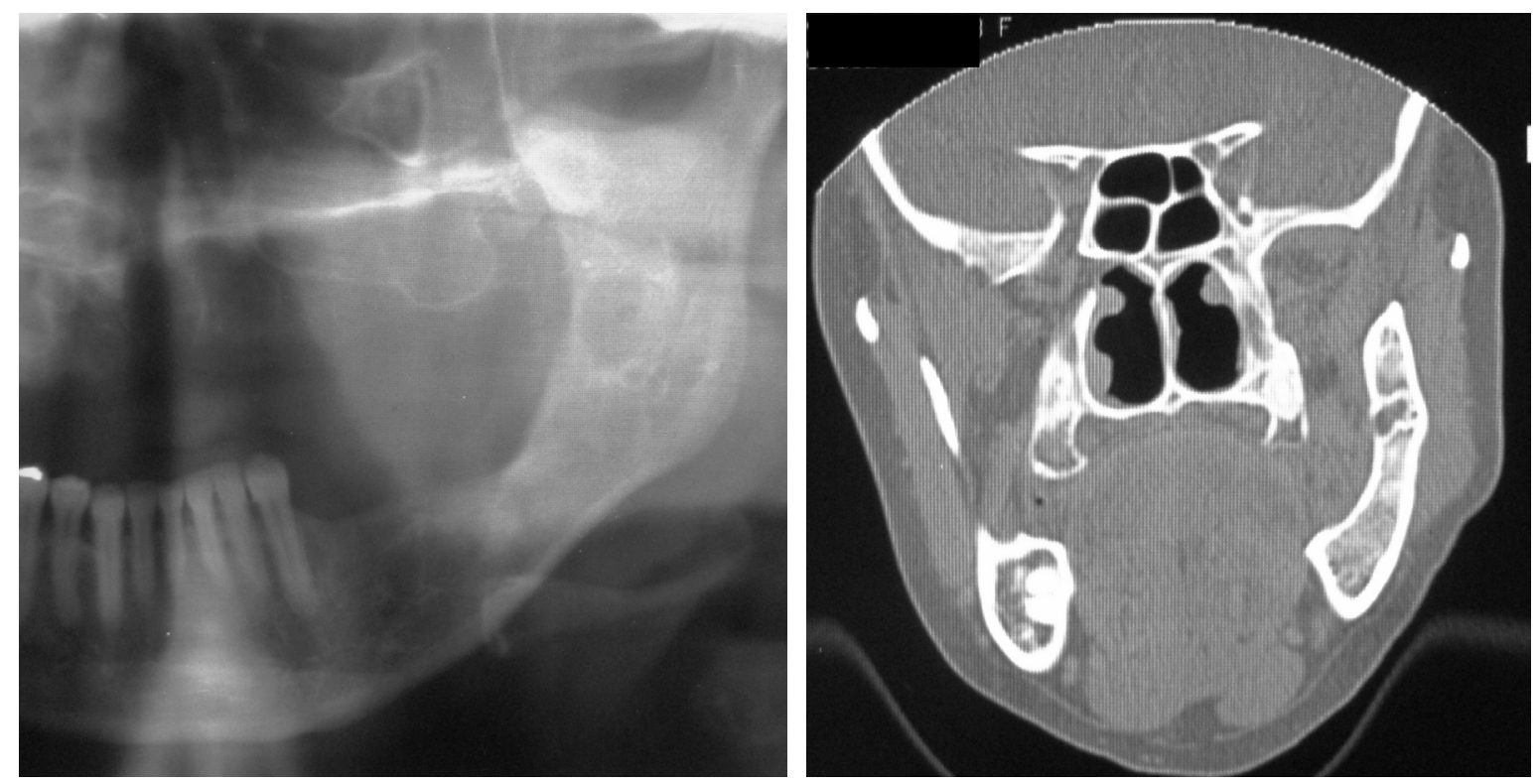

Figure 3 || A: Panoramic X-ray showing a radiolucent mandibular ramus. B: Bone CT scan showing a small lesion at the mandibular ramus, suggesting a recurrence of the neoplasia.
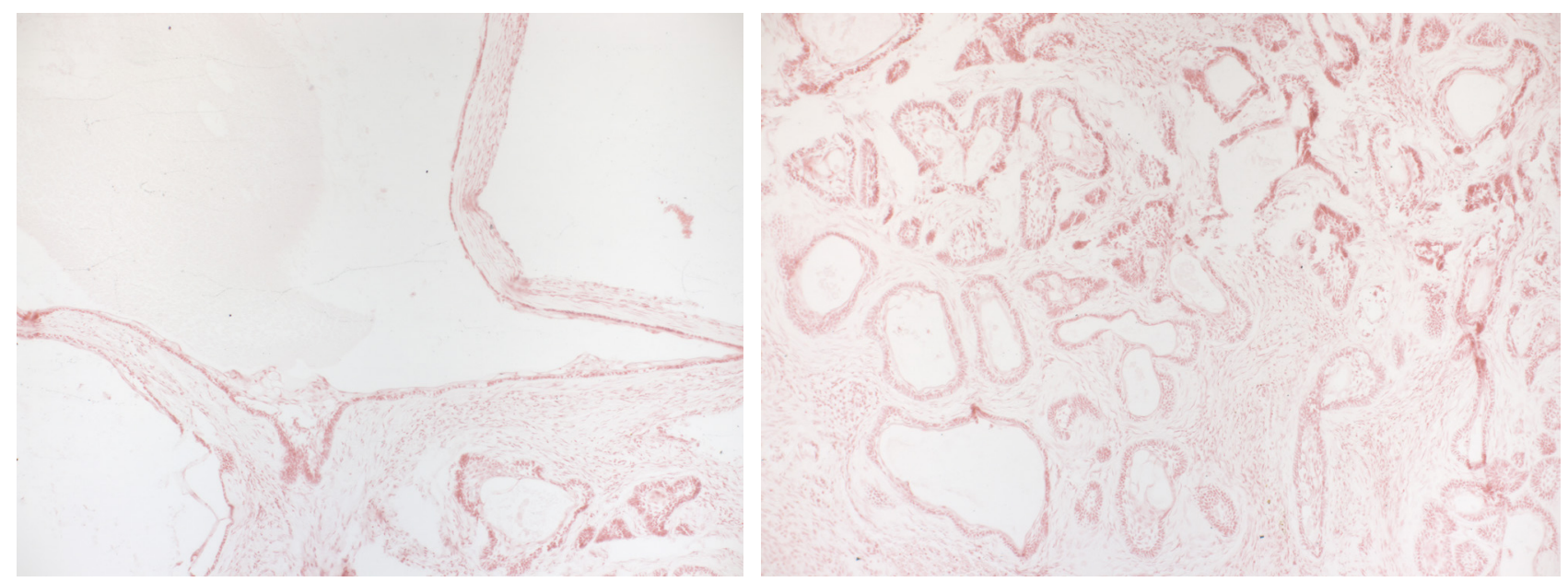

Figure 4 || A: Large cystic spaces covered by odontogenic epithelium. B: The stroma shows dense connective tissue with numerous odontogenic epithelial islands. They are more loosely arranged at the center, with a appearance similar to the stellate reticulum of the enamel organ. 


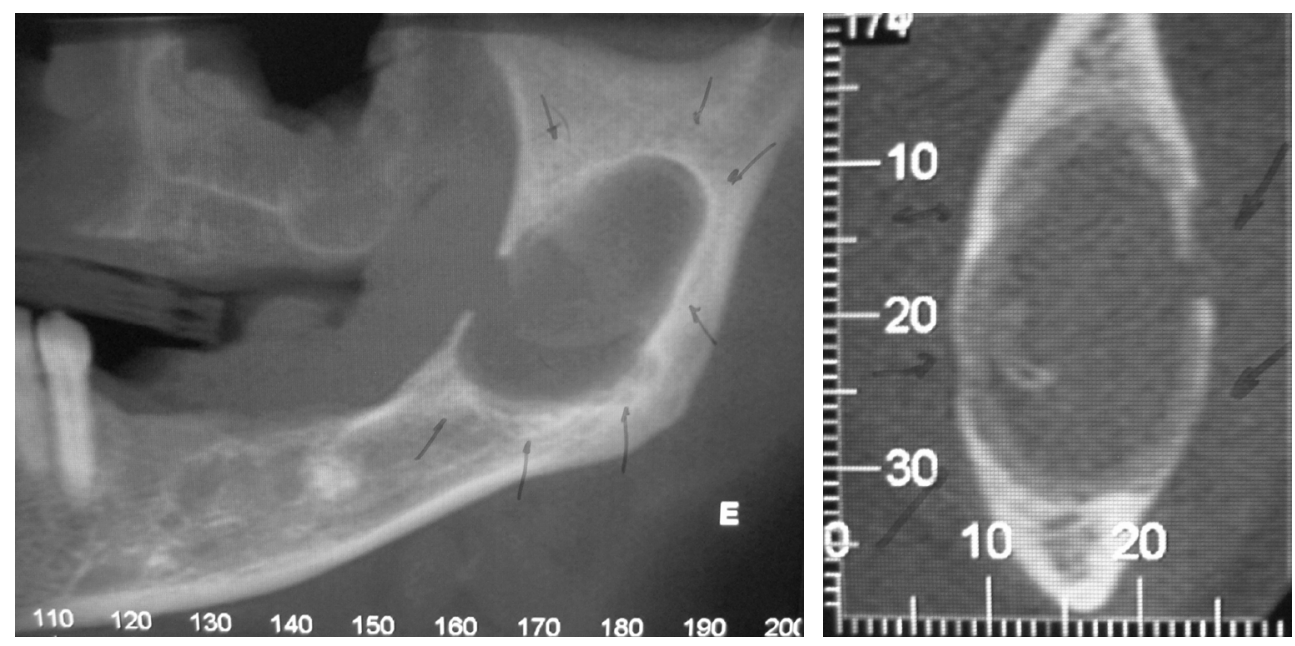

Figure 5 | A: Bone CT scan showing cortical rupture of the alveolar bone and a content with heterogeneous pattern. B: Parasagittal scan showing a heterogeneous aspect and the bone rupture of the anterior wall of the mandibular ramus.

After this treatment, the patient continued to be treated and there was no evidence of local recurrence for four years. However, after this period, the patient presented a new unilocular lesion in the same area (Figure 5). A new biopsy was performed and showed an ameloblastoma once more. Considering this result, a more aggressive approach of mandibular resection and reconstruction with iliac crest bone grafting was performed. The procedure was uneventful and the patient was released after two days. Currently, the patient is undergoing a postoperative period of four years with no signal of recurrence in the region.

\section{DISCUSSION}

The ameloblastoma is a locally invasive aggressive odontogenic tumour that can potentially present the behaviour of malignant lesions. Regarding treatment, many authors advocate resection with margins as model because of the high rates of recurrence and likelihood of distant metastasis. ${ }^{5,6}$

In cases of unilocular variant, these tumours can be classified into 3 variants, according to their histological appearance: luminal, intraluminal, and mural. Some authors suggest that the mural variant has a more aggressive behaviour and should be treated more amply.?

In addition to these histological variants, some authors have reported another classification of these neoplasias, called keratoameloblastoma. It differs from the others because it presents tumour islands characteristic of ameloblastoma with extensive keratinised areas. ${ }^{8}$

In a previous study, Whitt et al. ${ }^{9}$ studied the clinical and histological characteristics of 13 cases of keratoameloblastomas. They showed that these lesions had extensive keratinisation in the ameloblastic components and smaller areas of keratocyst, as in the abovementioned case.

Neuman et al. ${ }^{10}$ described a case of a hybrid tumour showing characteristics of both ameloblastoma and odontogenic keratocyst. These authors justified that these two tumours can develop in the same region because of the pluripotency of odontogenic epithelium. ${ }^{11}$ Geng et al. ${ }^{4}$ defined that, when keratinisation occurs on the cell surface and the dominant areas are keratocystic, these lesions should be classified as keratocyst with ameloblastic areas.

In this report, a case of recurrent unilocular ameloblastoma treated previously as odontogenic 
keratocyst was presented. We believe this mistake in the diagnosis and treatment may have occurred because of some factors:

1. Removal of only a small fragment of the lesion in the first surgery (only required for placement of the decompression device). This specific area with keratinisation of epithelium may not represent the entire lesion.

2. Limited view of the lesion during surgery showing suggested keratin material. This occurred because of the small incision made in the region under local anaesthesia, with the sole purpose of putting the device without additional surgical manipulation.

3. Histopathological examination imitating odontogenic keratocyst in an ameloblastoma because of a keratinisation area (keratoameloblastoma).

In conclusion, this article reiterates the importance of carrying out a proper biopsy in suggested lesions of ameloblastomas and/or odontogenic keratocyst. This should be done by removing multiple specimens in various regions of the lesion. In addition, a histopathological examination should be conducted by professionals in the area of odontogenic tumours because of the possibility of atypical lesions occurring restricted to the head and neck region. By taking these precautions, professionals will avoid diagnostic errors and wrong treatments.

\section{REFERENCES}

1. Gardner DG, Heikinheimo K, Shear M, Philipsen HP, Coleman H. Ameloblastoma. In: Barnes L, Eveson J, Reichart P, Sidransky D, editors. World Health Organization Classification of Tumours: pathology and genetics - head and neck tumours. Lyon: IARC Press; 2005. p. 296-300.

2. Taneeru S, Guttikonda VR, Yeluri S, Madala J. Granular cell ameloblastoma of jaw - Report of a case with an emphasis on its characterization. J Clin Exp Dent. 2013 Jul 1;5(3):e154-6. doi: $10.4317 /$ jced.51015.

3. Thillaikarasi R, Balaji J, Gupta B, Ilayarja V, Vani NV, Vidula $\mathrm{B}$, et al. Cystic granular cell ameloblastoma. J Maxillofac Oral Surg. 2010 Sep;9(3):310-3. doi: 10.1007/s12663-010oo83-y.

4. Geng N, Lv D, Chen QM, Zhu ZY, Wu RQ, He ZX, et al. Solid variant of keratocystic odontogenic tumor with ameloblastomatous transformation: a case report and review of the literature. Oral Surg Oral Med Oral Pathol Oral Radiol. 2012 Aug;114(2):223-9. doi: 10.1016/j.oooo.2011.11.023.

5. Almeida RA, Andrade ES, Barbalho JC, Vajgel A, Vasconcelos BC. Recurrence rate following treatment for primary multicystic ameloblastoma: systematic review and meta-analysis. Int J Oral Maxillofac Surg. 2016 Mar;45(3):359-67. doi: 10.1016/j.ijom.2015.12.016.

6. Chrcanovic BR, Gomez RS. Recurrence probability for keratocystic odontogenic tumors: an analysis of 6427 cases. J Craniomaxillofac Surg. 2017 Feb;45(2):244-251. doi: 10.1016/j. jcms.2016.11.010.

7. Probst FA, Probst M, Pautke Ch, Kaltsi E, Otto S, Schiel S, et al. Magnetic resonance imaging: a useful tool to distinguish between keratocystic odontogenic tumours and odontogenic cysts. Br J Oral Maxillofac Surg. 2015 Mar;53(3):217-22. doi: 10.1016/j.bjoms.2014.10.014.

8. Vered M, Buchner A, Dayan D, Shteif M, Laurian A. Solid variant of odontogenic keratocyst. J Oral Pathol Med. 2004 Feb;33(2):125-8.

9. Whitt JC, Dunlap CL, Sheets JL, Thompson ML. Keratoameloblastoma: a tumor sui generis or a chimera? Oral Surg Oral Med Oral Pathol Oral Radiol Endod. 2007 Sep;104(3):368-76. doi: 10.1016/j.tripleo.2006.07.025

10. Neuman AN, Montague L, Cohen D, Islam N, Bhattacharyya I. Report of two cases of combined odontogenic tumors: ameloblastoma with odontogenic keratocyst and ameloblastic fibroma with calcifying odontogenic cyst. Head Neck Pathol. 2015 Sep;9(3):417-20. doi: 10.1007/s12105-014-0601-1.

11. Zhang W, Chen Y, Geng N, Bao D, Yang M. A case report of a hybrid odontogenic tumour: ameloblastoma and adenomatoid odontogenic tumour in calcifying cystic odontogenic tumour. Oral Oncol Extra. 2006;42:287-90. doi: 10.1016/j.ooe.2006.07.003. 